\title{
Beneficiation of Low Grade Limestone from Madukkarai, Coimbatore District, Tamil Nadu, India
}

\author{
B. P. Ravi ${ }^{1, ~ *}$, S. J. G. Krishna ${ }^{2}$, M. R. Patil ${ }^{3}$, C. Rudrappa ${ }^{4}$, P. S. Kumar ${ }^{5}$, V. Rampur ${ }^{6}$ \\ Mineral Processing Department, VSKU PG Centre, Nandihalli, Sandur, India \\ Email address: \\ ravibelavadi@gmail.com (B. P. Ravi) \\ ${ }^{*}$ Corresponding author
}

\section{To cite this article:}

B. P. Ravi, S. J. G. Krishna, M. R. Patil, C. Rudrappa, P. S. Kumar, V. Rampur. Beneficiation of Low Grade Limestone from Madukkarai, Coimbatore District, Tamil Nadu, India. International Journal of Mineral Processing and Extractive Metallurgy. Vol. 2, No. 1, 2017, pp. 1-6. doi: 10.11648/j.ijmpem.20170201.11

Received: August 29, 2016; Accepted: September 10, 2016; Published: April 22, 2017

\begin{abstract}
A low grade Limestone from ACC mines, Madukkarai, Coimbatore district, Tamil Nadu, India, was subjected to beneficiation by cationic reverse flotation process with the aim of producing cement grade and metallurgical grade concentrates. The low grade limestone analyzed $43 \% \mathrm{CaO}, 76 \% \mathrm{TC}, 18 \% \mathrm{SiO}_{2}, 1.3 \% \mathrm{MgO}, 1.30 \% \mathrm{Fe}_{2} \mathrm{O}_{3}, 2.50 \% \mathrm{Al}_{2} \mathrm{O}_{3}, 0.33 \%$ alkalis and $36.00 \%$ LOI. It contained mainly calcite and quartz which were mutually intergrown with fair degree of liberation at 65 mesh size. Reverse cationic flotation was preferred to direct soap flotation, as practiced in beneficiation plant at Madukkarai. Inverse flotation studies were carried out to float siliceous impurities using cationic collectors varying collector type, collector dosage, mesh of grind and pulp density. Cement grade composite concentrate ( non-float and slimes) assaying 9.51\% AI, 90\% Total carbonates at wt.\% yield of 88 by a process comprising of grinding to MOG D80 400 microns, desliming/ screening over 400 mesh, rougher conditioning with $0.4 \mathrm{~kg} / \mathrm{t}$ SOKEM $565 \mathrm{C}$ for 2 minutes at $50 \% \mathrm{~S}$, rougher flotation for 4 minutes, at $\mathrm{pH} 8$ and $28 \% \mathrm{~S}$. The float sand fraction assaying $80.30 \% \mathrm{AI}, 18 \%$ total carbonates may be used as eco sand. On the contrary, premium metallurgical grade concentrate assaying $54.64 \% \mathrm{CaO}, 0.6 \% \mathrm{SiO}_{2}, 0.7 \% \mathrm{MgO}, 1.4 \% \mathrm{Fe}_{2} \mathrm{O}_{3}, 0.7 \%$ $\mathrm{Al}_{2} \mathrm{O}_{3}, 41.0 \%$ LOI with weight $\%$ yield of 55.2, could be produced at $20 \%$ solids, MOG $\mathrm{D}_{80} 400 \mathrm{microns}$, and $\mathrm{pH} 8 \mathrm{with} 1.0 \mathrm{~kg}$ $/ \mathrm{t}$ of SOKEM $565 \mathrm{C}$. The evolved nil waste process is stable, selective, and easily adaptable in the existing anionic soap direct flotation plant at ACC Madukkarai cement works, yielding valuable products.
\end{abstract}

Keywords: Flotation, Cationic Collectors, Limestone Flotation, Cement and Metallurgical Grades

\section{Introduction}

Limestone is used mainly in cement industry (69\%) followed by metallurgical industries $(12 \%)$, like, iron- $\&$ steel as fluxes, in agriculture as soil conditioner $(10 \%)$ and manufacturing industries $(9 \%)$, like, glass making, paper, water purification, filler in plastics (IBM (2013)) The specification for limestone for metallurgical industry is $\mathrm{CaO}>48 \%, \mathrm{SiO}_{2}<1.5 \%, \mathrm{Al}_{2} \mathrm{O}_{3}<1 \%, \mathrm{Fe}_{2} \mathrm{O}_{3}<2 \%, \mathrm{MgO}$ $<1 \%, \mathrm{Na}_{2} \mathrm{O}+\mathrm{K}_{2} \mathrm{O}<0.5 \%, \mathrm{P}<0.1 \%$ and $\mathrm{S}<0.1 \%$. The specification of limestone for cement industry is $\mathrm{CaO}>45 \%$, Total carbonates $>80 \%, \mathrm{SiO}_{2}<12 \%, \mathrm{MgO}<3 \%, \mathrm{Fe}_{2} \mathrm{O}_{3}<$ $5 \%,<5 \%+0.25 \mathrm{~mm}$ and $\sim 30 \%+0.09 \mathrm{~mm}$ (BIS: $10345-$ 2009).

Madukkarai is located $2.50 \mathrm{~km}$ away from Madukkarai Cement Works, which lies $10 \mathrm{~km}$ from Coimbatore.
Geographically the mining lease area (ML3) fall between the latitude $10^{\circ} 55^{\prime}$ to $10^{\circ} 56^{\prime}$ and longitude $76^{\circ} 56^{\prime}$ to $76^{\circ} 59^{\prime}$. The topography is gently undulated and surrounded by Calc - granulites hills. Country rock is garnetiferous sillimanite schist in most of the places, at places the limestone also occurs in association with charnockite and calc gneiss. Limestone bands of varying width are well exposed in roadside west block with intervening calc granulite bands. The limestone is greyish white and light to dark grey in colour, crystalline and coarse to fine grained in nature. It is generally observed that at the contact zone with calc granulite, the limestone is pink in colour. The limestone commonly shows inclusion of diopside, biotite, muscovite and graphite. Limestone bands are separated by calc granulite and at places there are thin lenses of calc granulite within the limestone band itself. Intrusions of pegmatite and occasional 
thin quartz veins are common within limestone. Occurrence of clay within the limestone is commonly observed. Since, 1965, ACC is mining low grade limestone by opencast mining method and is partly beneficiating to sweeter grade limestone for blending and using it with raw mix. It has a 4000 tpd cement manufacturing based on semi-wet process. Concentrate produced in the flotation plant assaying 83\% total carbonate is the feed to the cement kiln. Limestone up gradation process comprised of multistage crushing, grinding and flotation. The flotation plant is operated in two parallel lines at a rated capacity of 60-65 tph per line. Limestone received in the cement works from Madukkarai mine and $+15 \mathrm{~mm}$ fraction from Walayar mine in 1:1 ratio is mixed, crushed and screened at site in jaw and impact crushers to all $-15 \mathrm{~mm}$ size. This blend assaying $76-77 \%$ Total Carbonates forms the feed to two ball mills operated in close circuit with $350 \mathrm{~mm}$ hydrocyclones. Overflow from the hydrocyclone is deslimed in a cluster of $100 \mathrm{~mm}$ hydrocyclones. The overflow joins the concentrate thickener whereas the underflow constitutes the feed to flotation. Flotation is carried in two parallel batteries, one of Dorr-Oliver make and other of
Outokumpu make equipped with automatic level controller. Process flowsheet is given in figure 1. Each flotation battery has 12 cells. First 8 cells produce concentrate and last 4 cells are used as scavenger cells. The scavenger concentrate is fed back to the conditioner, whereas the scavenger tails forms the final rejects. The concentrate joins the thickener. Thickener underflow assays around $83 \%$ Total Carbonates and is the feed to cement kiln. The reject assays around $25-30 \%$ Total Carbonates. Anionic collector used in the flotation is a mixture of soap, resin and caustic soda. The reagents consumption is $1 \mathrm{~kg} / \mathrm{t}$ of $\mathrm{ROM}$ and is partly added in the conditioner and remaining in the various flotation cells. Though lot of work has been carried out on direct flotation of limestone from the study area (Sutone et. al, (2004) and Shandilya and Jha (2012)), little work has been done on inverse flotation of limestone in general except the works of Rao et. al. (2009), Vijayakumar et. al. (2003 and 2009) for cement grade and Rachappa Kadli et. al. (2014 and 2015) for metallurgical grade limestone. Hence, the aim of the present work was to beneficiate low grade limestone to cement and metallurgical grade.

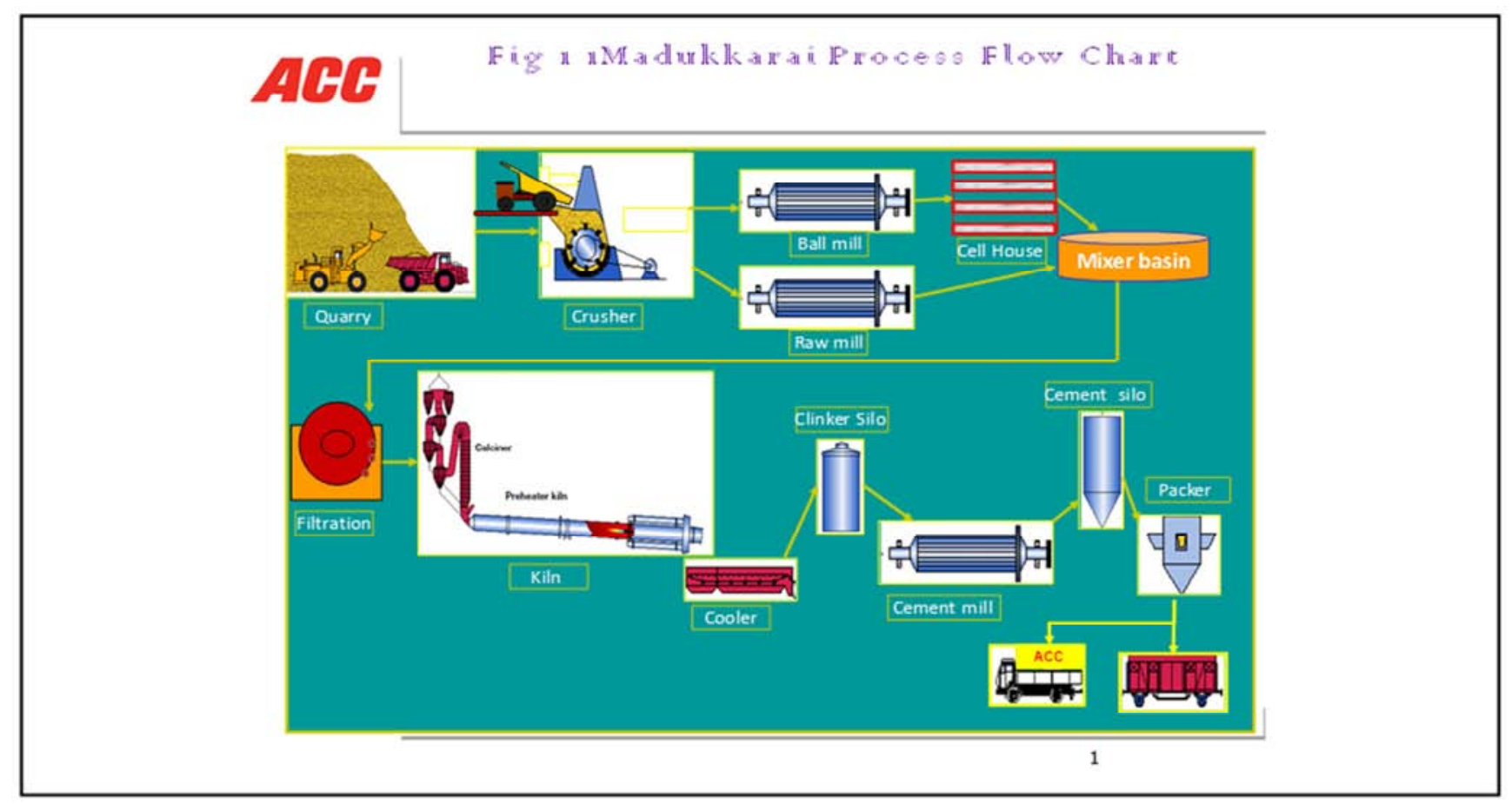

Fig. 1. ACC Madukkarai Process Flow Chart.

\section{Experimental}

Material and Methods; Lime stone samples of $200 \mathrm{kgs}$ was collected from Lime stone mining area of ACC mines, Madukkarai, Coimbatore district, Tamil Nadu, India. The flotation regents were collected from $\mathrm{M} / \mathrm{s}$ Somu organics Ltd., Bangalore. The as received sample was stage crushed to -10 mesh using primary lab jaw crusher $[150 \times 225 \mathrm{~mm}-25$ $\mathrm{mm}$ set], lab roll crusher [200mm x $150 \mathrm{~mm}] 300$ mmx600mm 16 mesh screen. The crushed sample was subjected to standard feed preparation by adopting sampling procedures. The sample was ground at $67 \% \mathrm{~S}$ in $175 \mathrm{~mm} \mathrm{x}$ $350 \mathrm{~mm}$ rod mill $5 \mathrm{~kg}$ rod charge -10 Nos. of $40 \mathrm{~mm}, 25 \mathrm{~mm}$ and $20 \mathrm{~mm}$ dia., varying grinding time. The ground pulp was subjected to froth flotation using D12 Denver type MPE lab sub aeration flotation machine. The feed and products after dewatering followed by drying were weighed, sampled and subjected to characterization studies. MOG, Kinetics, Choice of collector, Collector dosage and $\%$ solids were varied.

\section{Results and Disucussions}

Characterization studies; The whitish gray coloured 
limestone sample had bulk density of $1.81 \mathrm{t} / \mathrm{m}^{3}$ and $35^{\circ}$ angle of repose. The work index of the sample was found to be 11.5 $\mathrm{KWh} /$ short ton. The sample contained fine grained calcite intimately associated with minor amounts of fine grained aggregates of quartz, iron oxides, clay and trace amounts of feldspar. The sample was siliceous low grade granular limestone with fair degree of liberation at -65 mesh size. The sample analyzed $43 \% \mathrm{CaO}, 18 \% \mathrm{SiO}_{2}, 1.23 \% \mathrm{MgO}, 1.30 \%$ $\mathrm{Fe}_{2} \mathrm{O}_{3}, 1.50 \% \mathrm{Al}_{2} \mathrm{O}_{3}, 0.33$ alkalis $76 \%$ total carbonates and $36 \%$ LOI. The diagnostic amenability test on -65 mesh sample involving sink and float test at 2.8 specific gravity were conducted and observed 5\% acid insolubles in sink and slimes assayed $10 \%$ acid insoluble.

-16 mesh samples were ground in rod mill for varying time from 5 to 15 minutes and samples were subjected to size analysis. The data is given in Table 1 . The grindability data indicated that the sample was medium soft in nature

Table 1. Size analysis of rod mill grindability.

Conditions: 250 gms of - 16 mesh ground in $175 \mathrm{~mm} \times 350 \mathrm{~mm}$ rod mill with $5 \mathrm{~kg}$ rod charge at $67 \% \mathrm{~S}$ for time varying from 0/5/10/15minutes

\begin{tabular}{llllll}
\hline \multirow{2}{*}{ Mesh } & $\begin{array}{l}\text { Mesh size } \\
\text { in microns }\end{array}$ & \multicolumn{4}{l}{ Wt\% retained } \\
\cline { 3 - 6 } & $\mathbf{0}$ & $\mathbf{5}$, & $\mathbf{1 0}$ & $\mathbf{1 5}$ \\
\hline$-16+22$ & 1000 & 10.0 & 1.6 & 0 & 0 \\
$-22+30$ & 818 & 12.0 & 5.6 & 0 & 0 \\
$-30+52$ & 600 & 38.0 & 27.2 & 2.4 & 3.2 \\
$-52+72$ & 300 & 15.0 & 19.2 & 15.2 & 1.6 \\
$-72+120$ & 212 & 8.0 & 20.0 & 28.8 & 28.8 \\
$-120+200$ & 125 & 5.0 & 8.0 & 15.2 & 23.2 \\
$-200+277$ & 75 & 4.0 & 5.6 & 8.8 & 13.6 \\
$-277+400$ & 54 & 6.0 & 1.6 & 3.2 & 3.2 \\
-400 & 38 & 2.0 & 11.2 & 26.4 & 26.4 \\
& & & 100.0 & 100.0 & 100.0 \\
D 80 microns & & 730 & 400 & 200 & 150 \\
\hline
\end{tabular}

Effect of mesh of grind [MOG]: Inverse flotation tests were conducted varying mesh of grinding time $5 \% / 10^{\prime} / 15^{\prime}$ with respective $D_{80} 400 / 200 / 150$ microns respectively at natural $\mathrm{pH}$ of 8 , with $1 \mathrm{Kg} / \mathrm{t}$ anionic collector SOKEM 565 C. The results have been tabulated Table -2 and graphically represented in figure 2. The results indicated that the grade of silica content reduced to a minimum at mesh of grind of 400 microns and hence was chosen. The fall in grade in coarse grind of 150 microns was due to lack of liberation of silica values while the fall in grade in very fine grind of 200 microns was attributed to interference of slimes. Rao et.al. (2009), Vijayakumar et.al. (2009) and Rachappa Kadli et.al. (2015) obtained optimum MOG at grinds finer than 150 microns. Incidentally the present direct soap flotation process at Madukkarai plant employs a finer grind of 105 microns. From the experimental studies, it has been concluded that with mesh of grind of 5' D80 at 400 microns results obtained are encouraging.
Table 2. Effect of MOG on inverse flotation.

Conditions; Mesh of grind 5'110'15 'has $D_{80} 400 / 200 / 150$ microns Flotation pH 8,\% S 19,

\begin{tabular}{lllllll}
\hline Stage & Cell & Rpm & Reagent & Dosage kg/t & CT min & FT min \\
\hline RF & 250 & 1200 & SOKEM 565C & 1 & 2 & 4 \\
\hline
\end{tabular}

Results:

\begin{tabular}{lllll}
\hline \multirow{2}{*}{ Mesh of grind } & \multirow{2}{*}{ Product } & \multirow{2}{*}{ Wt\% } & \multicolumn{2}{c}{ Acid insoluble\% } \\
\cline { 4 - 5 } & & Assay & Distn \\
\hline \multirow{2}{*}{,} & Float reject & 40.8 & 41.60 & 98.2 \\
$\mathrm{D}_{80} 400$ microns & Non float & 59.2 & 0.60 & 1.8 \\
& Head Cal & 100.0 & 18.40 & 100.0 \\
10 & Float reject & 44.8 & 33.43 & 98.0 \\
$\mathrm{D}_{80} 200$ microns & Non float & 55.2 & 0.68 & 2.0 \\
& Head Cal & 100.0 & 18.83 & 100.0 \\
15 & Float reject & 59.2 & 31.10 & 97.8 \\
$\mathrm{D}_{80} 150$ microns & Non float & 40.8 & 1.00 & 2.2 \\
& Head cal & 100.0 & 18.79 & 100.0 \\
\hline
\end{tabular}

Effect of kinetics; Kinetics of inverse flotation was carried out using $1 \mathrm{~kg} / \mathrm{t}$ SOKEM $565 \mathrm{C}$ cationic collector for time intervals of $0.25,0.5,1.0,2.0$ and 4 minutes flotation time varying the MOG from $\mathrm{D}_{80} 400,200$ and 150 microns by varying grinding time $(5,10$ and 15 minutes). The results indicated that the kinetics of inverse flotation varying MOG followed first order equation. The results also showed that increase in coarseness of the MOG increases the flotation rate constant of siliceous gangue flotation with maximum at $\mathrm{D}_{80} 200$ microns. The distribution of \% AI increased with increase in coarseness of grind. Nikkam Suresh (2002) indicated that the water content, slime \% increases with increase in slime content of MOG during anionic flotation of limestone. The results are shown in figure 3.

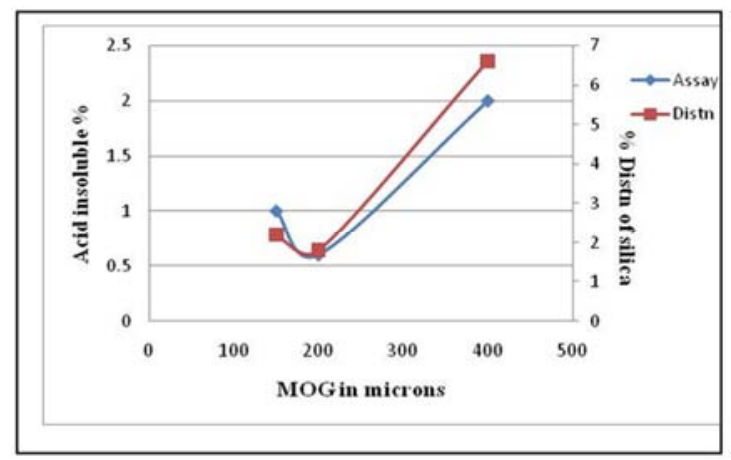

Fig. 2. Effect of MOG on inverse flotation.

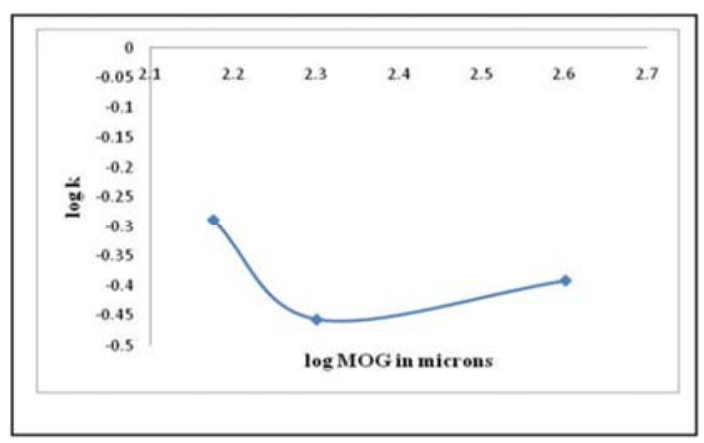

Fig. 3. Effect of MOG on rate constant. 
Table 3. Choice of collector on flotation

Conditions; Mesh of grind 5' $D_{80} 400$ microns, Flotation $\mathrm{pH} 8$, and\% $\mathrm{S} 19$

\begin{tabular}{lllllll}
\hline Stage & cell & Rpm & Reagent & Dosage $\mathbf{k g} / \mathbf{t}$ & CT min & FT min \\
RF & 250 & 1200 & SOKEM565C/524C/522C/503C & 1 & 2 \\
\hline
\end{tabular}

Results:

\begin{tabular}{lllll}
\hline \multirow{2}{*}{ Collector } & Product & \multirow{2}{*}{ Wt\% } & \multicolumn{2}{c}{ Acid insoluble\% } \\
\cline { 3 - 5 } & Assay & Distn \\
\hline SOKEM & Float reject & 50.8 & 41.60 & 98.2 \\
565C & Non float & 49.2 & 0.60 & 1.8 \\
& Head Cal & 100.0 & 18.96 & 100.0 \\
SOKEM & Float reject & 47.2 & 44.20 & 90.4 \\
524CC & Non float & 52.8 & 4.20 & 9.6 \\
& Head Cal & 100.0 & 23.09 & 100.0 \\
SOKEM & Float reject & 46.4 & 39.50 & 88.1 \\
522C & Non float concentrate & 53.6 & 4.60 & 11.9 \\
& Head Cal & 100.0 & 20.78 & 100.0 \\
SOKEM & Float reject & 46 & 33.10 & 88.4 \\
503C & Non float concentrate & 53.6 & 3.80 & 11.6 \\
\end{tabular}

Choice of collector: Inverse flotation tests were conducted at $\mathrm{D}_{80}$ size of 400 microns varying collectors like SOKEM 565C, SOKEM 524C, SOKEM 522C and SOKEM 503C and maintaining dosage of $1 \mathrm{~kg} / \mathrm{t}$. The results are shown in Table 3. The results indicated that SOKEM 565C was more selective in flotation of siliceous gangue. Incidentally obtained similar results with SOKEM 565C in case of reverse flotation of low grade limestone to get cement grade concentrate was obtained by Rao et.al (2009), Vijayakumar et.al. (2009) and Rachappa Kadli et.al (2015).

Table 4. Effect of \%S on inverse flotation.

Conditions; MOG $D_{80} 400$ microns, $p H 8$, SOKEM 565 C dosage $0.4 \mathrm{~kg} / t, \% \mathrm{~S}$ 19/33/47

\begin{tabular}{|c|c|c|c|c|c|c|}
\hline Stage & Cell & Rpm & Reagent & Dosage $\mathrm{kg} / \mathrm{t}$ & CT min & FT min \\
\hline $\mathrm{RF}$ & 250 & 1200 & SOKEM 565C & 0.4 & 2 & 4 \\
\hline \multirow{2}{*}{$\% \mathrm{~S}$} & \multirow{2}{*}{\multicolumn{3}{|c|}{ Product }} & \multirow{2}{*}{ Wt $\%$} & \multicolumn{2}{|c|}{ Acid insoluble\% } \\
\hline & & & & & Assay & Distn \\
\hline \multirow{3}{*}{19} & & at reje & & 32.8 & 41.30 & 75.2 \\
\hline & & in float & concentrate & 67.2 & 6.60 & 24.8 \\
\hline & & $\mathrm{ad} \mathrm{Cal}$ & & 100.0 & 18.10 & 100.0 \\
\hline \multirow{3}{*}{33} & & at reje & & 26.4 & 40.68 & 40.7 \\
\hline & & on float & concentrate & 73.6 & 10.00 & 59.3 \\
\hline & & $\mathrm{ad} \mathrm{Cal}$ & & 100.0 & 18.10 & 100.0 \\
\hline \multirow{3}{*}{47} & & at reje & & 20.0 & 24.06 & 25.9 \\
\hline & & in float & concentrate & 80.0 & 17.18 & 74.1 \\
\hline & & $\mathrm{ad} \mathrm{Cal}$ & & 100.0 & 18.55 & 100.0 \\
\hline
\end{tabular}

Effect of pulp density on flotation: Flotation tests were conducted varying $\%$ of solids from 20/47. Increase in $\%$ of solids though increases yield, but reduces selectivity. Tests were conducted by varying pulp density $19 / 33 / 47 \%$ S. The results are given in Table-4. Incidentally similar results were obtained by Rao et.al(2009) by working on flotation of low grade limestone samples of Andrapradesh. This may be attributed to better dispersion of air bubbles in the pulp and better dropping of entrapped silica in the froth. But to obtain low silica metallurgical grade concentrate $20 \%$ solids seems to be optimum. Shandilya and Jha (2012) while working in ACC Madukkarai flotation plant opined that $20-24 \%$ S was found optimum for maximum selectivity, total carbonate recovery and productivity.

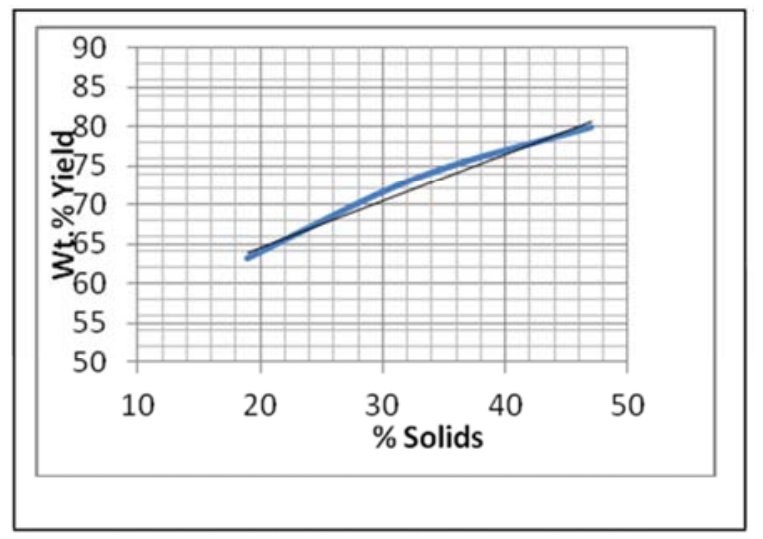

Fig. 4[a]. Effect of\%Solids on Wt.\% yield.

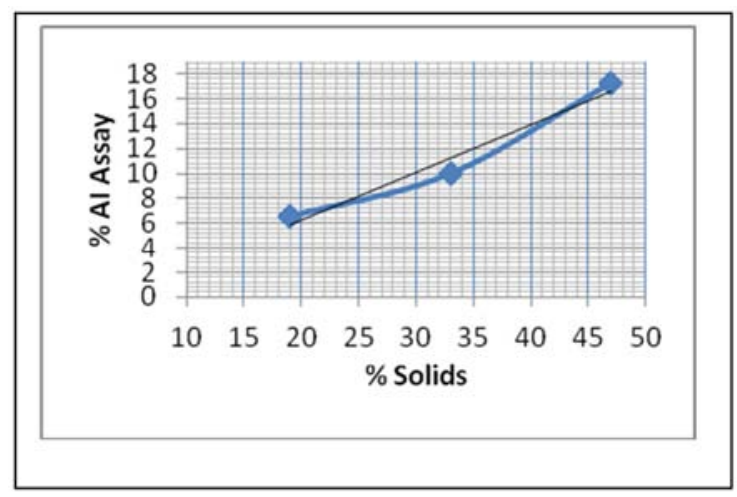

Fig. 4[b]. Effect of\%Solids on\% AI assay.

Collector dosage variation: Tests were conducted at $\mathrm{D}_{80}$ size of 400 microns by varying collector SOKEM 565C dosage from 0.4 to $1.2 \mathrm{~kg} / \mathrm{t}$. The results are shown in Table 5 . Result indicated that the increase in collector dosage 
decreased $\mathrm{Wt} \%$ yield and \% AI grade (except at $1.2 \mathrm{~kg} / \mathrm{t}$ dosage) with a best result at $1.0 \mathrm{~kg} / \mathrm{t}$. Rao et. al (2009) obtained optimum results at $0.6 \mathrm{~kg} / \mathrm{t}$ SOKEM $565 \mathrm{C}$ for cement grade concentrate. Rachappa Kadli et. al. (2015) produced metallurgical grade concentrate with $1.0 \mathrm{~kg} / \mathrm{t}$ SOKEM $565 \mathrm{C}$. Hence, to produce cement grade concentrate $0.4 \mathrm{~kg} / \mathrm{t}$ of collector is sufficient to float less gangue while to produced metallurgical grade concentrate with low silica 1.0 $\mathrm{kg} / \mathrm{t}$ of collector may be required to remove siliceous gangue which is logical.

Table 5. Effect of collector SOKEM 565 C Dosage variation.

Conditions; Mesh of grind 5', $D_{80} 400$ microns, Flotation $\mathrm{pH} 8$, and\% $\mathrm{S} 19$

\begin{tabular}{lllllll}
\hline Stage & Cell & Rpm & Reagent & Dosage kg/t & CT min & FTmin \\
\hline RF & 250 & 1200 & SOKEM 565C & $0.4 / 0.6 / 0.8 / 1.0 / 1.2$ & 2 & 4 \\
\hline Results; & & & &
\end{tabular}

\begin{tabular}{lllll}
\hline $\begin{array}{l}\text { SOKEM 565 C } \\
\text { dosage } \mathbf{~ k g / t}\end{array}$ & Product & Wt\% & \multicolumn{2}{c}{ Acid insoluble\% } \\
\cline { 4 - 5 } $0.4 \mathrm{~kg} / \mathrm{t}$ & Float reject & 32.8 & 41.30 & Distn \\
\hline & Non float & 67.2 & 6.60 & 24.8 \\
& Head Cal & 100.0 & 18.00 & 100.0 \\
$0.6 \mathrm{~kg} / \mathrm{t}$ & Float reject & 47.2 & 35.00 & 92.1 \\
& Non float & 52.8 & 2.70 & 7.9 \\
& Head Cal & 100.0 & 17.90 & 100.0 \\
$0.8 \mathrm{~kg} / \mathrm{t}$ & Float reject & 48.8 & 34.30 & 92.9 \\
& Non float & 51.2 & 2.50 & 7.1 \\
& Head Cal & 100.0 & 18.00 & 100.0 \\
$1.0 \mathrm{~kg} / \mathrm{t}$ & Float reject & 50.8 & 41.60 & 98.2 \\
& Non float & 49.2 & 0.60 & 1.8 \\
& Head Cal & 100.0 & 18.96 & 100.0 \\
$1.2 \mathrm{~kg} / \mathrm{t}$ & Float reject & 56.8 & 31.00 & 98.8 \\
& Non float & 43.2 & 0.90 & 2.2 \\
& Head Cal & 100.0 & 18.00 & 100.0 \\
\hline
\end{tabular}

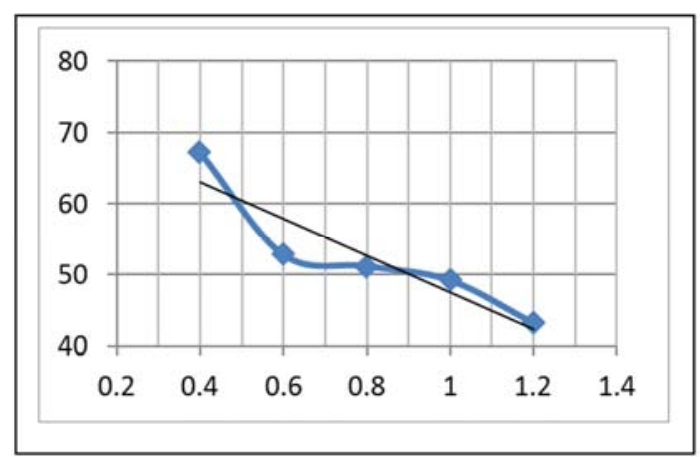

Fig. 5[a]. Effect of SOKEM565Ckg/t on Wt\% yield.

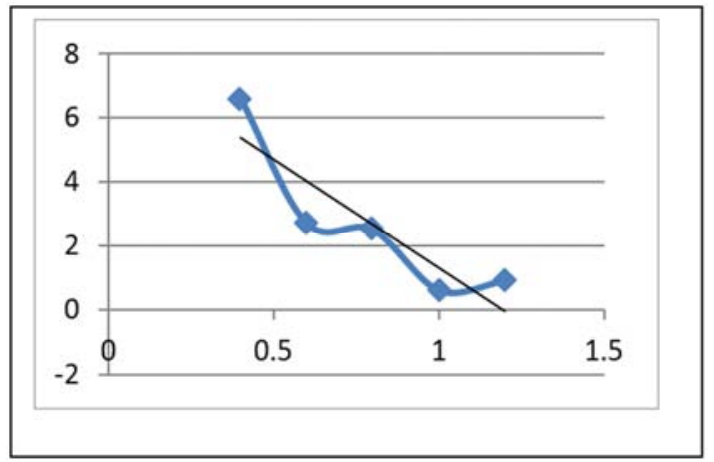

Fig. 5[b]. Effect of SOKEM565Ckg/t on\% AI grade.
Final test under optimum conditions: Test under optimum conditions of $20 \%$ solids, MOG $\mathrm{D}_{80} 400$ microns, natural $\mathrm{pH}$ 8 , collector conditioning time of 2 minutes and flotation time of 4 minutes in each stage with $0.4 \mathrm{~kg} / \mathrm{t}$ SOKEM $565 \mathrm{C}$ in I stage and $0.6 \mathrm{~kg} / \mathrm{t}$ SOKEM $565 \mathrm{C}$ in II stage for floating the residual silica in I stage non float were conducted. The results are given in Table 6.The I stage flotation with $0.4 \mathrm{~kg} / \mathrm{t}$ collector produced concentrate assaying $52.00 \% \mathrm{CaO}, 6.6 \%$ $\mathrm{SiO}_{2}, 1.17 \% \mathrm{MgO}, 1.7 \% \mathrm{Fe}_{2} \mathrm{O}_{3}, 1.0 \% \mathrm{Al}_{2} \mathrm{O}_{3}, 37.0 \%$ LOI with weight $\%$ yield of 67.2 , meeting the cement grade specifications. The 2 stage flotation with $1 \mathrm{~kg} / \mathrm{t}$ collector produced a concentrate assaying $54.64 \% \mathrm{CaO}, 97 \% \mathrm{TC}, 0.6 \%$ $\mathrm{SiO}_{2}, 0.7 \% \mathrm{MgO}, 1.4 \% \mathrm{Fe}_{2} \mathrm{O}_{3}, 0.7 \% \mathrm{Al}_{2} \mathrm{O}_{3}, 41.0 \%$ LOI with weight $\%$ yield of 55.2 meeting the metallurgical specification.

Table 6. Result of final test under optimum conditions.

Conditions; MOG $D_{80} 400$ microns, pH 8, SOKEM 565C dosage 1.0kg/t,\% S 20

\begin{tabular}{lllllll}
\hline \multicolumn{2}{l}{ Stage Cell } & Rpm & Reagent & Dosage kg/t & CT min & FT min \\
\hline RF1 & 250 & 1200 & SOKEM 565C & 0.4 & 2 & 4 \\
RF2 & 250 & 1200 & SOKEM 565C & 0.6 & 2 & 4 \\
\hline
\end{tabular}

Results;

\begin{tabular}{llll}
\hline & & \multicolumn{2}{c}{ Acid insoluble\% } \\
\cline { 3 - 4 } Product & Wt\% & Assay & Distn \\
\hline RF1 reject & 32.8 & 41.38 & 75.4 \\
RF2 reject & 8.0 & 51.30 & 22.8 \\
NF2 (Met grade conc) & 59.2 & 0.60 & 1.8 \\
Head Cal & 100.0 & 18.00 & 100.0 \\
RF1+RF2 reject & 40.8 & 39.45 & 98.2 \\
NF2+RF2 Cal (Cem grade conc) & 67.2 & 6.60 & 24.6 \\
\hline
\end{tabular}

Final test for cement grade concentrate production; The test comprised of grinding the sample to MOG $\mathrm{D}_{80} 400$ microns, desliming/ screening over 400 mesh, rougher conditioning with $0.4 \mathrm{~kg} / \mathrm{t}$ SOKEM565C for 2 minutes at $50 \% \mathrm{~S}$, rougher flotation for 4 minutes at $\mathrm{pH} 8$ and $28 \% \mathrm{~S}$. The non-float and slimes constituted the final concentrate. The test was carried out to simulate the industrial condition. The results are given in Table 7 . The results indicate that a composite of slime and deslimed non float yielded a cement grade assaying $9.51 \%$ AI, 90\% Total carbonates at wt $\%$ yield of 88 . The concentrate size was coarse $\left[\mathrm{D}_{80} 0.3 \mathrm{~mm}\right]$ w.r.t. ACC concentrate $\left[\mathrm{D}_{80} 0.2 \mathrm{~mm}\right]$. The float sand fraction assaying $80.30 \% \mathrm{AI}, 18 \%$ total carbonates may be used as eco sand. Incidentally, Shandilya (2012) recommended the flotation rejects as ACC eco sand for plastering and concrete works. The above desliming- inverse flotation nil waste process appears to be stable, easily adaptable at site,producing raw materials for civil construction like ACC Eco sand as an alternative to river sand and cement grade limestone. 
Table 7. Result of final test simulating plant conditions.

Conditions; MOG $D_{80} 400$ microns, wet screening over 400 mesh for removing slimes in -400 mesh fraction, + 400 mesh sand subjected to flotation.

\begin{tabular}{llllllllll}
\hline \multirow{2}{*}{ Stage } & \multirow{2}{*}{ Cell } & \multirow{2}{*}{ Rpm } & \multirow{2}{*}{ Reagent } & $\begin{array}{l}\text { Dosage } \\
\text { kg/t }\end{array}$ & \multicolumn{2}{l}{ CT } & \multicolumn{3}{c}{ FT } \\
\cline { 5 - 9 } & & & & \%S & min & \%S & min \\
\hline RF & 250 & 1200 & SOKEM 565C & 0.4 & 50 & 2 & 28 & 4 \\
\hline
\end{tabular}

Results;

\begin{tabular}{llll}
\hline \multirow{2}{*}{ Product } & \multirow{2}{*}{ Wt\% } & \multicolumn{2}{c}{ Acid insoluble\% } \\
\cline { 3 - 4 } & & Assay & Distn \\
\hline -400 mesh slimes conc. & 12.0 & 12.00 & 8.0 \\
Non float conc. & 76.0 & 9.12 & 38.5 \\
Float reject (Eco sand by product) & 12.0 & 80.30 & 53.5 \\
Head Cal & 100.0 & 18.00 & 100.0 \\
$-400 \#+$ RNF Conc (Cem grade) Cal & 88.0 & 9.51 & 46.5 \\
\hline
\end{tabular}

\section{Conclusions}

A low grade Limestone from ACC mines, Madukkarai, Coimbatore district, Tamil Nadu, India assaying 43\% $\mathrm{CaO}$, $76 \% \mathrm{TC}, 18 \% \mathrm{SiO}_{2}, 1.3 \% \mathrm{MgO}, 1.30 \% \mathrm{Fe}_{2} \mathrm{O}_{3}, 2.50 \% \mathrm{Al}_{2} \mathrm{O}_{3}$, $0.33 \%$ alkalis and $36.00 \%$ LOI yielded a cement grade composite concentrate ( non-float and slimes) assaying $9.51 \%$ AI, $90 \%$ Total carbonates at wt $\%$ yield of 88 by a process comprising of grinding to MOG $\mathrm{D}_{80} 400$ microns, desliming/ screening over 400 mesh, rougher conditioning with $0.4 \mathrm{~kg} / \mathrm{t}$ SOKEM $565 \mathrm{C}$ for 2 minutes at $50 \% \mathrm{~S}$, rougher flotation for 4 minutes at $\mathrm{pH} 8$ and $28 \% \mathrm{~S}$. The float $(-16+400$ mesh) sand fraction assaying $80.30 \% \quad \mathrm{AI}, 18 \%$ total carbonates may be used as eco sand. The evolved nil waste process is stable, selective, and easily adaptable in the existing anionic soap direct flotation plant at ACC Madukkarai cement works. Alternatively, a premium metallurgical grade concentrate assaying 54.64\% $\mathrm{CaO}$, 97\% TC, $0.6 \%$ AI, $0.7 \% \mathrm{MgO}, 1.4 \% \mathrm{Fe}_{2} \mathrm{O}_{3}, 0.7 \% \mathrm{Al}_{2} \mathrm{O}_{3}$, $41.0 \%$ LOI with weight $\%$ yield of 55.2 , could be produced at MOG $\mathrm{D}_{80} 400$ microns, $19 \%$ Solids with $1.0 \mathrm{~kg} / \mathrm{t}$ of SOKEM $565 \mathrm{C}$. The low grade siliceous crystalline limestone from Madukkarai is amenable to inverse flotation process. Detailed tests for process confirmation and data generation for conceptual design are recommended.

\section{Acknowledgements}

The authors are thankful to M/s ACC Ltd (Madukkarai) and SOCL, Bangalore for arranging the limestone and reagent samples respectively.

\section{References}

[1] IBM, (2013), Indian Mineral Year Book, Limestone, Chapter 32, pp 32.1-32.6.

[2] Nikkam Suresh, R Venugopal and TC Rao (2002), Analysis of particle size effects in limestone flotation Proc MPT 2002, IISc, Bangalore, pp 332-337.

[3] TV Vijaykumar, DS Rao,S.Subba Rao, G Bhaskar Raju and S Prabhakar (2003) Beneficiation of a low grade limestone by Flotation,MPT-2003 Panjim, pp-194-207.

[4] AT Sutone and Amanullah, (2004), Performance Evaluation of Limestone Beneficiation Plant of M/S. Associated Cement Company Limited at Madukkarai Cement Works, Proc MPT 2004, IMMT Bhubaneshwar pp MPT-21.1 -21.4.

[5] TV Vijayakumar, DS Rao, S Subba Rao, S Prabhakar and G Bhaskar Raju, (2009), Direct and reverse flotation studies on a siliceous limestone, Proc.MPT2009 IMMT Bhubaneshwar, pp MPT 73.1-73.6.

[6] DS Rao, T. V. Vijaya Kumar, S. Prabhakar and G.Bhaskar Raju, (2009): AT Mineral Processing., vol. 50. pp. 36-47.

[7] A.Shandilya and LM Jha (2012), Optimization of froth flotation reagents for limestone beneficiation in the cement industry: XXVI IMPC, New Delhi, pp-12.4913-12.4920.

[8] A. Shandilya (2012), sage of froth flotation reject as sand, XXVI IMPC, New Delhi, pp-675.4922-675.4930.

[9] Rachappa Kadli, Gajula Suresh Ram, M V Rudramuniyappa and B P Ravi (2014), Beneficiation of Limestone from Bagalkot, Karnataka for Metallurgical Industry, IJERT, 3(3), pp 2095-7.

[10] Rachappa Kadli, M V Rudramuniyappa, B P Ravi, B Suresh and Balavantappa (2015), Reduction of Silica from Limestone of Bagalkot, Karnataka, Proc. MPT 2014, Andhra University, Vishakapatnam. 